\title{
Studies on the nature and significance of connective tissue antibodies in adult coeliac disease and Crohn's disease
}

\author{
A. F. N. MAGalhaes, T. J. Peters, AND William F. DOE \\ From the Department of Medicine, Royal Postgraduate Medical School, London
}

SUMMARY Sera from 92 patients with adult coeliac disease, 20 patients with Crohn's disease, and 89 control patients were tested for the presence and immunoglobulin class of anticonnective tissue antibodies. In adult coeliac disease patients taking a normal diet there was a high frequency of sera positive for connective tissue antibodies and the majority were IgA in class. Following gluten withdrawal, IgA class connective tissue antibody activity was strikingly reduced. No such antibody activity was detected in concentrated jejunal fluid collected from 15 patients with adult coeliac disease, seven of whose sera were positive for connective tissue antibody.

Connective tissue antibody activity was not absorbed by fractions of gluten. Similarly, preparations of human reticulin and glomerular basement membrane together with elastin and collagen failed to absorb connective tissue antibody.

Serum antibodies, apparently directed against components of connective tissue, are found in coeliac disease, Crohn's disease, dermatitis herpetiformis, and in some patients with selective IgA deficiency whose jejunal mucosa is normal (Seah, Fry, Hoffbrand, and Holborow, 1971a; von Essen, Savilahti, and Pelkonen, 1972; Seah, Fry, Holborow, Rossiter, Doe, Magalhaes, and Hoffbrand, 1973). They are more commonly present in coeliac patients taking a normal diet than in those on a gluten-free diet (Alp and Wright, 1971; Seah et al, 1973). The presence of these antibodies may prove a useful test in the diagnosis of coeliac disease, especially in children where a high proportion of untreated coeliac patients give positive results (Seah, Fry, Rossiter, Hoffbrand, and Holborow, 1971b). Little is known, however, about the pathogenetic significance of these antibodies, their immunoglobulin class, or the nature of the antigen(s) against which they are directed. The similarity of the immunofluorescent staining pattern of connective tissue (CT) antibodies to that seen following a silver stain for reticulin has led some authors to assume that these antibodies are directed against reticulin (Seah et al, 1971a). Others, however, report a similar tissue staining pattern in coeliac patients with selective IgA deficiency and suggest that the antibodies are directed against basement membrane (Ammann and Hong, 1971).

Received for publication 30 January 1974.
The purpose of this paper is to investigate the significance of connective tissue antibodies. Studies were carried out to determine the immunoglobulin class of these antibodies in adult coeliac disease and their relationship to gluten withdrawal. Jejunal fluid was collected from coeliac patients and tested for connective tissue antibody activity to investigate the site of secretion of the antibody. In addition connective tissue antibody testing was performed on sera from patients with Crohn's disease, ulcerative colitis, and a wide variety of chronic disorders in which antibodies have been reported. A series of absorption tests using fractions of gluten and isolated connective tissue components were carried out to study the specificity of these antibodies.

\section{Materials and Methods}

\section{PATIENTS STUDIED}

Sera was obtained from patients suffering from adult coeliac disease, 92; Crohn's disease, 20; ulcerative colitis, 10; chronic liver disease, 11 (cirrhosis six; chronic aggressive hepatitis two; infectious hepatitis one; haemochromatosis one; chlorpromazine cholestasis one); chronic lymphatic leukaemia, nine; intestinal lymphoma, six; chronic renal disease, 16 (glomerulonephritis 13, pyelonephritis one, rapidly progressive glomerulonephritis one, chronic hypertension one); sero-positive rheumatoid arthritis 10 ; and 25 healthy members of 
the laboratory staff. The adult coeliac disease group comprised 70 females and 22 males, the age range being 12 to 65 years. Forty-four sera were taken from those of the patients receiving a normal diet and 73 from those who had been taking a gluten-free diet for at least three months. A single gluten challenge was administered to six patients with adult coeliac disease successfully treated with a gluten-free diet as described by Doe, Henry, Holt, and Booth (1972).

\section{ANTIBODY IN SERUM}

Sera were diluted 1 in 10 and tested by indirect fluorescence on unfixed cryostat sections of rat kidney, liver, and stomach as described by Seah $e t$ al (1971a). Rabbit fluorescein-conjugated antibody to combined human IgG, IgA, and IgM (Wellcome) and class-specific rabbit fluorescein-conjugated antihuman IgG, IgA, and IgM (Behringwerke and Hyland Laboratories) were used at appropriate dilutions for antibody detection and classifying. Unconjugated immunoglobulin class-specific antisera (Behringwerke) were used in blocking control tests. Stained tissue sections were viewed using a Leitz Orthoplan microscope. Sera were considered to be positive when the characteristic 'reticulin pattern' (Seah et al, 1971a) staining peritubular connective tissue and Bowman's capsule in kidney, portal tract, and sinusoids in liver and linear fibres between gastric glands in stomach were seen. Renal tissue was the most sensitive substrate and when the connective tissue antibody titre was low it was sometimes the only tissue which gave a positive reaction. At the same time, the presence or absence of the staining patterns characteristic of smooth muscle antibody was noted (Doniach, Roitt, Walker, and Sherlock, 1966).

\section{JEJUNAL FLUID}

Jejunal fluid was collected from 15 patients with adult coeliac disease and two normal subjects. Proteinases were inactivated by heating jejunal fluid to $56^{\circ} \mathrm{C}$ for 30 minutes and by the addition of Trasylol. The fluid was concentrated 10 times by vacuum dialysis using collodion bags and tested for the presence of connective tissue antibody as already described.

\section{ABSORPTION STUDIES}

Absorption studies were carried out using $1 \%$ and $0.1 \%$ preparations of crude gluten, gliadin (British Drug Houses), and a peptic-tryptic digest of gluten (Frazer, Fletcher, Ross, Shaw, Sammons, and Schneider, 1959). 'Collagenous' reticulin (Eastoe and Courts, 1963a) and 'non-collagenous' reticulin (Pras and Glynn, 1973) were isolated from the cortex of human kidneys. The products were characterized by determining their amino acid composition which was found to be in close agreement to those reported (Eastoe and Courts, 1963a; Pras and Glynn, 1973). Acid-soluble rat tail collagen was prepared as described by Eastoe and Courts (1963b). In addition calf skin collagen (Worthington Laboratories), bovine elastin (Sigma Laboratories), and human glomerular basement membrane prepared as described by Spiro (1967) were used in absorption studies at a concentration of $1 \%$ in phosphatebuffered saline. Fifteen sera known to be connective tissue antibody positive were used in absorption tests. Each serum was tested at a dilution of 1 in 10 and also at the maximum dilution which still showed a positive result. Sera were incubated with each of these preparations at room temperature and at $37^{\circ} \mathrm{C}$ for one to 20 hours before being tested for the presence of connective tissue antibody as already described.

\section{Results}

PREVALENCE AND IMMUNOGLOBULIN CLASS OF CONNECTIVE TISSUE ANTIBODIES The results are shown in table I. Thirty-six of 92 adult coeliac patients had connective tissue antibodies in their serum. Thirteen of these were IgA class, 16 were IgG, and seven sera contained connective tissue antibody activity of both IgA and IgG classes. In addition, this antibody was found in five out of 20 Crohn's disease sera and in all five positive sera

\begin{tabular}{|c|c|c|c|c|c|c|}
\hline \multirow[t]{2}{*}{ Group } & \multirow[t]{2}{*}{ No. of Patients } & \multirow{2}{*}{$\begin{array}{l}\text { Connective Tissue } \\
\text { Antibody Positive }\end{array}$} & \multicolumn{4}{|c|}{ Immunoglobulin Class } \\
\hline & & & $\operatorname{Ig} A$ & $\operatorname{Ig} G$ & $I g M$ & $I g A+I g G$ \\
\hline $\begin{array}{l}\text { Adult coeliac disease } \\
\text { Crohn's disease } \\
\text { Chronic liver disease } \\
\text { Lymphomas and chronic lymphatic leukaemia } \\
\text { Ulcerative colitis } \\
\text { Chronic renal disease } \\
\text { Rheumatoid arthritis } \\
\text { Normal adults }\end{array}$ & $\begin{array}{l}92 \\
20 \\
11 \\
17 \\
10 \\
16 \\
10 \\
25\end{array}$ & $\begin{array}{l}36(39 \%) \\
5(25 \%) \\
1 \\
1 \\
0 \\
0 \\
0 \\
0\end{array}$ & $\begin{array}{r}13 \\
0 \\
0 \\
0 \\
0 \\
0 \\
0 \\
0\end{array}$ & $\begin{array}{r}16 \\
5 \\
1 \\
1 \\
0 \\
0 \\
0 \\
0\end{array}$ & $\begin{array}{l}\mathbf{0} \\
\mathbf{0} \\
\mathbf{0} \\
\mathbf{0} \\
\mathbf{0} \\
\mathbf{0} \\
\mathbf{0} \\
\mathbf{0}\end{array}$ & $\begin{array}{l}7 \\
0 \\
0 \\
0 \\
0 \\
0 \\
0 \\
0\end{array}$ \\
\hline
\end{tabular}

Table I Prevalence and class of connective tissue antibodies 


\begin{tabular}{|c|c|c|c|c|c|}
\hline \multirow[t]{2}{*}{ Adult Coeliac Disease Group } & \multirow[t]{2}{*}{ No. of Patients } & \multirow{2}{*}{$\begin{array}{l}\text { Connective Tissue } \\
\text { Antibody Positive }\end{array}$} & \multicolumn{3}{|c|}{ Connective Tissue Antibody Class } \\
\hline & & & $\operatorname{Ig} A$ & IgG & $I g A+I g G$ \\
\hline
\end{tabular}

Table II Relationship between connective tissue antibodies and gluten withdrawal in adult coeliac patients ${ }^{1} \chi^{2}=12.00 \mathrm{P}<0.001$

these antibodies were IgG class. While there was no significant difference between the prevalence of connective tissue antibody activity in the adult coeliac group taken as a whole, and that in Crohn's disease $\left(\chi^{2}=0.87 ; P>0.05\right)$, a significant difference was present when results in coeliac patients taking a normal diet were compared with those in Crohn's disease $\left(\chi^{2}=4.39 ; P<0.05\right)$. By contrast, connective tissue antibodies were only found in one patient with chronic liver disease and in a further patient suffering from chronic lymphatic leukaemia. No IgM class connective tissue antibody activity was observed in the positive sera and no positive reactions were observed in the 25 normal subjects studied.

\section{RELATION TO GLUTEN WITHDRAWAL}

The frequency and immunoglobulin class of connective tissue antibodies in coeliac patients on a normal diet and in those taking a gluten-free diet are shown in table II. Twenty-five out of $44(58 \%)$ sera from coeliac patients taking a normal diet were positive for connective tissue antibody and $\operatorname{IgA}$ was the major antibody class. By contrast only 17 out of $73(23 \%)$ sera were positive in those on a gluten-free diet and IgG class antibody predominated. The difference in connective tissue antibody frequency in these two groups was statistically significant $\left(\chi^{2}=12.00 ; P<0.001\right)$.

Fifteen untreated coeliac patients whose sera were connective tissue antibody positive were studied again following three months' or more treatment on a gluten-free diet. In nine patients connective tissue antibody activity disappeared following gluten withdrawal and in five there was a reduction in antibody titre. This alteration in connective tissue antibody activity following gluten withdrawal was most marked for IgA connective tissue antibody activity which disappeared in eight of 10 sera following treatment.

\section{GLUTEN CHALLENGE}

When a single 30-gram gluten challenge was given by intraduodenal tube to six successfully treated coeliac patients whose jejunal mucosa had returned to normal, only one patient (whose serum was connective tissue antibody positive before challenge) was positive 48 hours and four weeks after challenge. No connective tissue antibody activity after challenge was detected in the five patients whose sera before challenge were negative.

\section{JEJUNAL FLUID}

No connective tissue antibody activity was observed in concentrated jejunal fluid collected from seven adult coeliac patients whose sera were connective tissue antibody positive in high titre. Similarly jejunal fluid collected from coeliac patients whose sera were connective tissue antibody negative and from two normal subjects showed no connective tissue antibody activity.

\section{ABSORPTION STUDIES}

Details of absorption tests are shown in table III. Connective tissue antibody activity of both IgG and IgA class in 15 high titre sera was unaffected by absorption with gluten, gliadin, and a peptictryptic digest of gluten. Furthermore, absorption studies using these sera showed that after incubation with preparations of 'collagenous' and 'noncollagenous' human reticulin, rat tail collagen,

\begin{tabular}{lll}
\hline Patients & $\begin{array}{l}\text { Connective Tissue } \\
\text { Antibody Titre }\end{array}$ & $\begin{array}{l}\text { Results of Absorption Tests } \\
\text { Using Compounds 1-12 }\end{array}$ \\
\hline GF & $1 / 128$ & NA \\
DG & $1 / 128$ & NA \\
MP & $1 / 80$ & NA \\
SM & $1 / 128$ & NA \\
IW & $1 / 16$ & NA \\
SS & $1 / 32$ & NA \\
MF & $1 / 64$ & NA \\
PF & $1 / 64$ & NA \\
SB & $1 / 40$ & NA \\
KG & $1 / 80$ & NA \\
BM & $1 / 32$ & NA \\
TM & $1 / 40$ & NA \\
OT & $1 / 40$ & NA \\
CB & $1 / 80$ & NA \\
JC & $1 / 128$ & NA \\
\hline
\end{tabular}

Table III Results of absorption tests

${ }^{1}$ Compounds used in absorption tests: (1) $1 \%$ gluten (BDH), (2) $0.1 \%$ gluten, (3) $1 \%$ gliadin (BDH), (4) $0.1 \%$ gliadin, (5) $1 \%$ peptic-tryptic digest of gluten, (6) $0.1 \%$ peptic-tryptic digest of gluten, (7) $1 \%{ }^{\circ} \mathrm{Col}-$ lagenous' human reticulin, (8) $1 \%$ 'non-collagenous' human reticulin, (9) $1 \%$ rat tail collagen, '(10) $1 \%$ calf skin collagen, (11) $1 \%$ bovine elastin, (12) $1 \%$ human glomerular basement membrane 'NA $=$ no absorption 
calf skin collagen, bovine elastin, and human glomerular basement membrane, connective tissue antibody titres in all 15 sera were undiminished.

\section{STAINING PATTERNS OF CONNECTIVE TISSUE ANTIBODIES}

Considerable heterogenicity of staining patterns was seen in the coeliac sera. In kidney tissue the characteristic 'reticulin' pattern outlines peritubular connective tissue, Bowman's capsule, and adventitial fibres around blood vessels. In addition two further renal patterns were seen. In seven sera there was diffuse staining of the glomerular tuft in addition to the 'reticulin' pattern. In one further serum only proximal renal tubular connective tissue stained. The 'reticulin' liver pattern showed staining of connective tissue fibres around portal tracts and in liver sinusoids. In some sera the portal tract connective tissue alone was outlined. In other sera there were variations in the extent and coarseness of the sinusoidal 'fibres' stained. Six sera showed a distinctive hexagonal pattern which outlined hepatocytes. The gastric tissue pattern consisted of linear fibres between gastric glands and in the submucosa.

\section{SMOOTH MUSCLE ANTIBODY}

Twelve coeliac sera (13\%) were positive for smooth muscle antibody. Of these 12 sera, 10 were also connective tissue antibody positive, both smooth muscle and connective tissue antibodies being $\operatorname{IgA}$ class. Five of the six sera containing antibody giving a hexagonal staining pattern were also smooth muscle positive.

\section{Discussion}

These results confirm the high frequency of connective tissue antibody in adult coeliac disease and in Crohn's disease. Single positive results were found in sera from patients with cirrhosis and chronic lymphatic leukaemia, reinforcing the view that connective tissue antibody activity is a non-specific but infrequent occurrence in a wide variety of disorders (Alp and Wright, 1971; Seah et al, 1973; Brown, Ferguson, Carswell, Horne, and MacSween, 1973). Such findings impair the usefulness of the connective tissue antibody as a diagnostic aid, especially in adults presenting with gastrointestinal symptoms. IgA class connective tissue antibody activity was practically confined to sera from adult coeliac patients taking a normal diet. Although the number of connective-tissue-positive patients with other diseases is relatively small, all had IgG class antibody. Withdrawal of gluten from the diet had a striking effect on connective tissue antibodies in coeliac sera, resulting in the almost complete disappearance of IgA class antibody but had little effect on IgG antibody. These findings could suggest that the IgA class connective tissue antibody present in serum reflects a local intestinal secretory antibody response either to connective tissue antigens in the diet or to mucosal antigens exposed by tissue damage. However, no detectable connective tissue antibody was found in the jejunal fluid of coeliac patients whose sera contained connective tissue antibody of both classes in high titre. While the presence of proteases in jejunal fluid makes antibody detection more difficult, the absence of connective tissue antibody activity in jejunal fluid militates against a local secretory immune response.

Our studies do not confirm the report alluding to cross reactivity between connective tissue antibody and gluten (Seah, Fry, Stewart, Chapman, Hoffbrand, and Holborow, 1972). Careful absorption studies using crude gluten and some of its subfractions failed to diminish connective tissue antibody activity of either IgA or IgG class. Furthermore, we were unable to absorb connective tissue antibodies using preparations of human reticulins, collagen or elastin, suggesting that connective tissue antibody is not directed specifically against any of these connective tissue components. We have, therefore, used the term 'connective tissue antibody' to describe the staining pattern which appears to outline connective tissue, apparently due to antibody activity against unknown connective tissue antigens.

Variations in connective tissue antibody-staining patterns suggest that some connective tissue antibodies are directed against a number of different antigens. The association of hexagonal liver staining pattern and smooth muscle antibody activity has been previously described (Holborow, 1972). There is evidence that parenchymal liver cell damage exposes 'sheltered' antigens, which are similar to smooth muscle actomyosin, resulting in cross reactivity (Holborow, 1972). The association of both smooth muscle antibody and the hexagonal pattern with connective tissue antibody suggests that connective tissue antibodies in some instances reflect the exposure of a number of tissue antigens in a damaged mucosa. The absence of connective tissue antibodies in patients with intestinal mucosal damage due to tropical sprue (Seah et al, 1973) and milk allergy (von Essen et al, 1972), however, suggests that mucosal damage alone is insufficient to explain the occurrence of connective tissue antibodies. The finding of connective tissue antibodies in patients with selective IgA deficiency but a structurally normal jejunal mucosa implies that defective antigen handling by the intestinal mucosa may also play a significant part in the formation of connective tissue antibodies. While the nature of the antigens against which 
connective tissue antibodies are directed remains obscure, it seems likely that these antibodies result from a combination of tissue damage and defective antigen handling and are unlikely to be of pathogenetic significance.

We are grateful to Dr E. J. Holborow and Dr P. Seah for their advice and to Professor C. C. Booth for his enthusiastic encouragement.

A.F.N.M. is in receipt of a grant from Fundaçao De Amparo A Pesquiza Do Estado De Sao Paulo (FAPESP), Brazil.

\section{References}

Alp, M. H., and Wright, R. (1971). Autoantibodies to reticulin in patients with idiopathic steatorrhoea, coeliac disease, and Crohn's disease, and their relation to immunoglobulins and dietary antibodies, Lancet, 2, 682-685.

Ammann, A. J., and Hong, R. (1971). Unique antibody to basement membrane in patients with selective IgA deficiency and coeliac disease. Lancet, 1, 1264-1266.

Brown, I. L., Ferguson, A., Carswell, F., Horne, C. H. W., and MacSween, R. N. M. (1973). Autoantibodies in children with coeliac disease. Clin. exp. Immunol., 13, 373-382.

Doe, W. F., Henry, K., Holt, L., and Booth, C. C. (1972). An immunological study of adult coeliac disease. Gut, 13, 324-325.

Doniach, D., Roitt, I. M., Walker, J. G., and Sherlock, S. (1966). Tissue antibodies in primary biliary cirrhosis, active chronic (lupoid) hepatitis, cryptogenic cirrhosis and other liver diseases and their clinical implications. Clin. exp. Immunol., 1, 237-262.

Eastoe, J. E., and Courts, A. (1963a). The soluble fractions of collagen. In Practical Analytical Methods for Connective Tissue Proteins, pp. 7-8. Spon, London.

Eastoe, J. E., and Courts, A. (1963b). Substances associated with the connective tissues. (a) Reticulin. In Practical Analytical Methods for Connective Tissue Proteins, pp. 15-17. Spon, London.

von Essen, R., Savilahti, E., and Pelkonen, P. (1972). Reticulin antibody in children with malabsorption. Lancet, 1, 1157-1159.

Frazer, A. C., Fletcher, R. F., Ross, C. A. C., Shaw, B., Sammons, H. G., and Schneider, R. (1959). Gluten-induced enteropathy: the effect of partially digested gluten. Lancet, 2, 252-255.

Holborow, E. J. (1972). Smooth muscle autoantibodies, viral infections and malignant disease. Proc. roy. Soc. Med., 65, 481-484.

Pras, M., and Glynn, L. E. (1973). Isolation of a non-collagenous reticulin component and its primary characterization. Brit. $J$. exp. Path., 54, 449-456.

Seah, P. P., Fry, L., Hoffbrand, A. V., and Holborow, E. J. (1971a). Tissue antibodies in dermatitis herpetiformis and adult coeliac disease. Lancet, 1, 834-836.

Seah, P. P. Fry, L., Holborow, E. J., Rossiter, M. A., Doe, W. F, Magalhaes, A. F., and Hoffbrand, A. V. (1973). Anti-reticulin antibody: incidence and diagnostic significance. Gut, 14, 311-315.

Seah, P. P., Fry, L., Rossiter, M. A., Hoffbrand, A. V., and Holborow, E. J. (1971b). Anti-reticulin antibodies in childhood coeliac disease. Lancet, 2, 681-682.

Seah, P. P., Fry, L., Stewart, J. S., Chapman, B. L., Hoff brand, A. V., and Holborow, E. J. (1972). Immunoglobulins in the skin in dermatitis herpetiformis and coeliac disease. Lancet, 1, 611-614.

Spiro, R. G. (1967). Studies on the renal glomerular basement membrane. J. biol. Chem., 242, 1915-1922. 